\title{
Enterococcus aquimarinus sp. nov., isolated from sea water
}

Correspondence

Pavel Švec

mpavel@sci.muni.cz

\author{
Pavel Švec, ${ }^{1}$ Marc Vancanneyt, ${ }^{2}$ Luc A. Devriese, ${ }^{3}$ Sabri M. Naser, ${ }^{2,4}$ \\ Cindy Snauwaert, ${ }^{2}$ Karen Lefebvre, ${ }^{2}$ Bart Hoste $^{2}$ and Jean Swings ${ }^{2,4}$ \\ ${ }^{1}$ Czech Collection of Microorganisms, Faculty of Science, Masaryk University, Tvrdého 14, \\ 60200 Brno, Czech Republic \\ ${ }^{2,4} \mathrm{BCCM} / \mathrm{LMG}$ Bacteria Collection ${ }^{2}$ and Laboratory of Microbiology, Faculty of Sciences ${ }^{4}$, \\ Ghent University, Ledeganckstraat 35, B-9000 Ghent, Belgium \\ ${ }^{3}$ Laboratory of Veterinary Bacteriology and Mycology, Faculty of Veterinary Medicine, \\ Ghent University, Salisburylaan 133, B-9820 Merelbeke, Belgium
}

Enterococci are Gram-positive cocci inhabiting various environments. They are generally considered to be commensal inhabitants of warm-blooded animals, including humans, but are also isolated from reptiles and insects. Moreover, they occur on different kinds of food and can be found on plants and in water (Devriese et al., 1992). It has become impossible to achieve a reliable identification using classical biochemical tests as the number of enterococcal species with validly published names has increased. For some of the more recently described Enterococcus species, characteristics traditionally considered to be typical for the genus, e.g. acetoin production, ribose acidification, resistance to $6.5 \% \mathrm{NaCl}$ and growth at 10 and $45{ }^{\circ} \mathrm{C}$, are no longer applicable (Devriese et al., 1993; Devriese \& Pot, 1995; Domig et al., 2003). Other methods, such as SDSPAGE analysis of whole-cell proteins, have been used intensively as routine and validated identification systems for

Published online ahead of print on 27 May 2005 as DOI 10.1099/ ijs.0.63722-0.

Abbreviation: rep-PCR, repetitive-element polymerase chain reaction.

The GenBank/EMBL/DDBJ accession number for the 16S rRNA gene sequence of Enterococcus aquimarinus sp. nov. LMG $16607^{\top}$ is AJ877015.

A phylogenetic tree based on pheS gene sequence comparisons of LMG $16607^{\top}$ and LMG 16612 with other enterococcal species is available as supplementary material in IJSEM Online. enterococci (Devriese et al., 2002; De Graef et al., 2003; Vancanneyt et al., 2004).

The present study deals with two strains presumptively assigned as Enterococcus sp. in the large BCCM/LMG inhouse database containing SDS-PAGE whole-cell protein profiles of all described lactic acid bacteria. Both strains, LMG $16607^{\mathrm{T}}\left(=\mathrm{CCM} 7283^{\mathrm{T}}\right)$ and LMG 16612 (=CCM 7284 ), originate from sea water and were deposited in BCCM/LMG in 1995 via bioMérieux with strain numbers API 8407116 and API 8407104, respectively. BioMérieux collected the strains in 1984 from the Istituto Superiore di Sanita of Roma, Italy. Further inquiries to determine the origin of the strains were unsuccessful. The taxonomic position of both sea-water isolates was further elucidated in this work. The reference strains used for comparison in this study were obtained from the BCCM/LMG bacteria collection (http://www.belspo.be/bccm/).

To determine the phylogenetic position of the sea-water isolates, $16 \mathrm{~S}$ rRNA gene sequence analysis was performed on one strain, LMG $16607^{\mathrm{T}}$, as described by Vancanneyt et al. (2004). The sequence obtained (a continuous stretch of $1510 \mathrm{bp}$ ) was aligned with reference sequences obtained from GenBank and edited by using the BioEdit program (Hall, 1999) and ForCon (Raes \& Van De Peer, 1999). Evolutionary distances were calculated using the Jukes \& Cantor evolutionary model and a phylogenetic tree was 


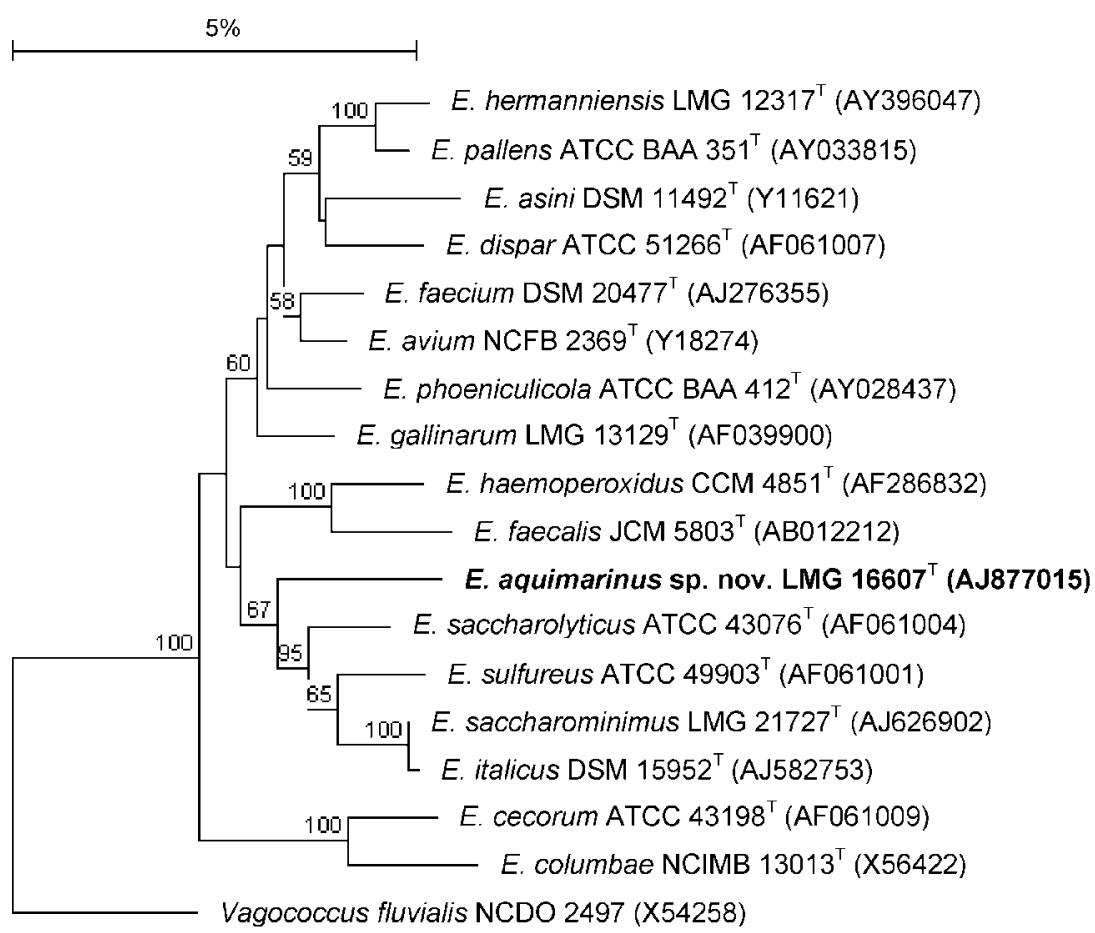

Fig. 1. Distance matrix tree based on $16 \mathrm{~S}$ rRNA gene sequence comparisons showing the phylogenetic relationships of $E$. aquimarinus sp. nov. and selected enterococcal species representing different phylogenetic lineages. The Vagococcus fluvialis (X54258) sequence was used as the outgroup. Bootstrap percentage values (500 tree replications) higher than $50 \%$ are indicated at the branch points. GenBank accession numbers in parentheses. Bar, $5 \%$ sequence divergence. constructed using the neighbour-joining method with TREECON software (Van De Peer \& De Wachter, 1994). Based on 16S rRNA gene sequencing, it was found that strain LMG $16607^{\mathrm{T}}$ represented a separate lineage distantly related to the other enterococci (see Fig. 1). The closest similarities were obtained with Enterococcus saccharolyticus (96.9\%), Enterococcus sulfureus (96.3\%), Enterococcus saccharominimus $(96 \cdot 5 \%)$ and Enterococcus italicus $(96 \cdot 1 \%)$. The $16 \mathrm{~S}$ rRNA gene similarity of strain LMG $16607^{\mathrm{T}}$ with its closest neighbour, E. saccharolyticus, was slightly below $97 \%$, a value that is generally accepted as the boundary value for the delineation of species (Stackebrandt \& Goebel, 1994). This indicates that both strains represent a separate species and excludes the need for DNA-DNA hybridizations. The separate species status of the sea-water isolates was confirmed by other validated phenotypic and genotypic methods as detailed below.

A comparison of whole-cell protein profiles from the sea-water isolates with all described enterococcal species grouped them separately. Whole-cell protein extracts were prepared from cells grown for $24 \mathrm{~h}$ on MRS agar (Oxoid) at $37^{\circ} \mathrm{C}$. SDS-PAGE, densitometric analysis of protein profiles and numerical analysis were performed in accordance with the procedure described by Pot et al. (1994). Fig. 2 shows protein profiles obtained from strains LMG $16607^{\mathrm{T}}$ and LMG 16612 and demonstrates their separate position from the phylogenetically closest species E. saccharolyticus, E. sulfureus, E. saccharominimus and E. italicus.

The separate taxonomic position of the sea-water isolates was also confirmed by using repetitive-element PCR (repPCR), a genomic screening method, using the $(\mathrm{GTG})_{5}$ primer. DNA preparation, amplification, separation, analysis of the rep-PCR fingerprint profiles by BioNumerics version 4.0 software and dendrogram construction were performed as described by Gevers et al. (2001). Strains LMG $16607^{\mathrm{T}}$ and LMG 16612 showed visually identical (GTG) $5^{-}$ PCR patterns and they were clearly separated from fingerprints obtained from other enterococcal species (Fig. 3).

Naser et al. (2005) investigated the usefulness of housekeeping genes as alternative phylogenetic and identification tools for all enterococcal species based on recent in silico studies of the whole genome sequences of different bacterial groups. Primers for the gene that encodes phenylalanyltRNA synthase, pheS, were designed using 12 pheS gene sequences from lactic acid bacteria. The pheS primers

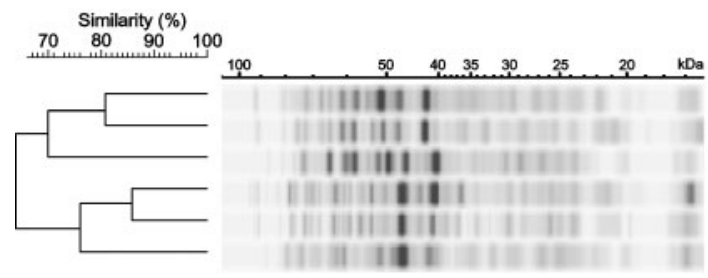

E. italicus LMG 22039

E. saccharominimus LMG $21727^{\top}$ E. sulfureus LMG $13084^{\top}$

E. aquimarinus sp. nov. LMG 16612 E. aquimarinus sp. nov. LMG $16607^{\top}$ E. saccharolyticus LMG $11427^{\top}$
Fig. 2. Protein profiles of strains LMG $16607^{\top}$, LMG 16612 and the type strains of phylogenetically related species. The dendrogram was constructed by UPGMA linkage of correlation coefficients ( $r$, expressed for convenience as percentage values). 


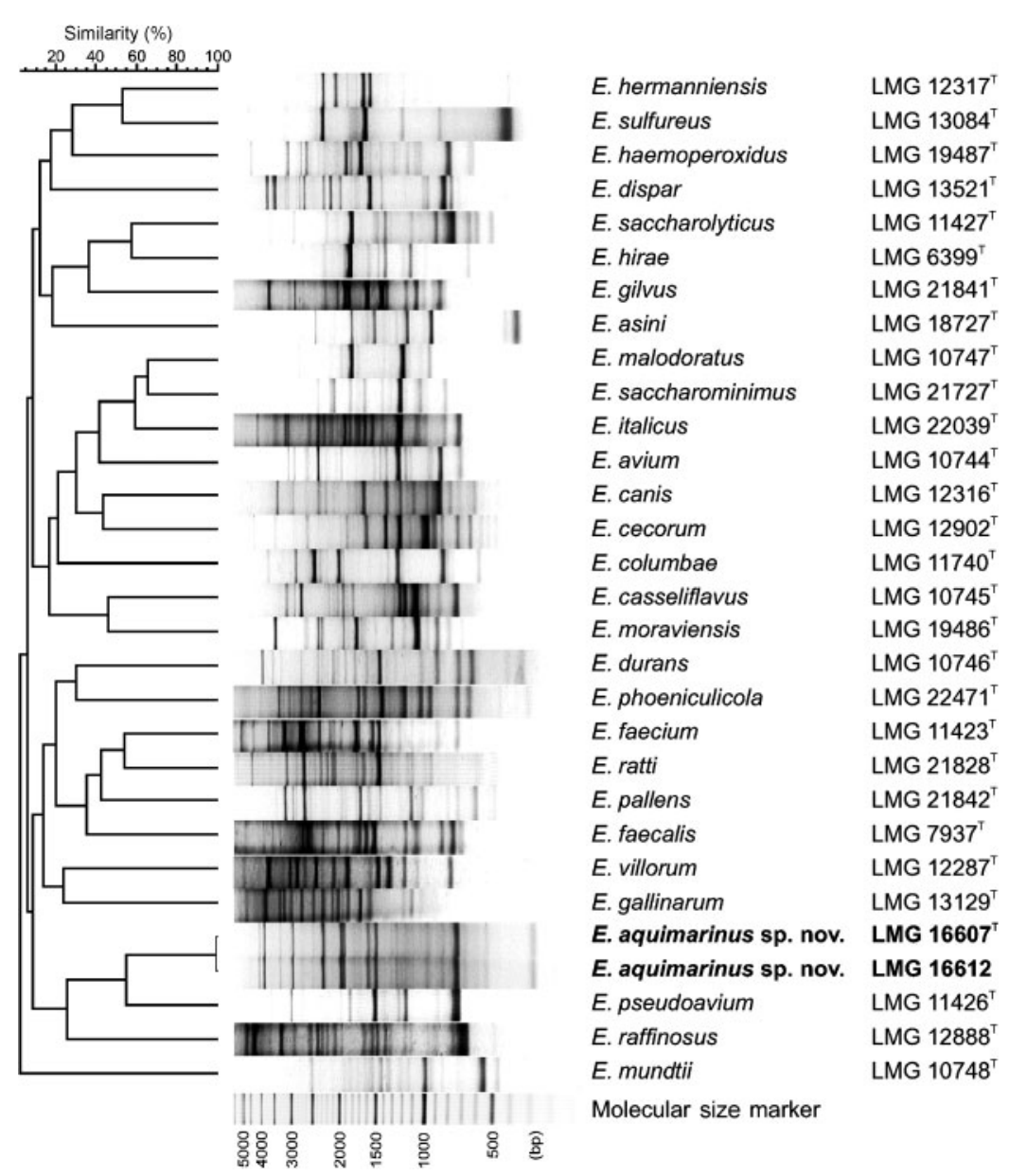

Fig. 3. Dendrogram based on (GTG) $)_{5}-P C R$ results obtained from strains LMG $16607^{\top}$ and LMG 16612 and from the type strains representing all enterococcal species with validly published names. The dendrogram was constructed with the Pearson correlation coefficient using the UPGMA method ( $r$, expressed for convenience as percentage similarity values).

enabled the amplification and sequencing of a $455 \mathrm{bp}$ pheS fragment from all of the described Enterococcus species (Table 1). The conditions for amplification and sequencing reactions are described elsewhere (Naser et al., 2005). Consensus sequences were determined using two reads for the pheS gene. Different enterococcal species had a maximum of $86 \%$ pheS gene sequence similarity, indicating that pheS is a fast-evolving clock and a valuable tool for the identification of all the currently described enterococcal species. Evaluation of intraspecies variation showed that pheS genes had a high degree of homogeneity, at least $97 \%$, within strains of the same species. Sequence analysis of the pheS gene confirmed that the sea-water isolates LMG $16607^{\mathrm{T}}$ and LMG 16612 are members of a single species (100\% similarity) and

Table 1. Primers that enabled the amplification and sequencing of a 455 bp pheS fragment from all Enterococcus species with validly published names

\begin{tabular}{|llc|}
\hline Primer & \multicolumn{1}{c|}{ Sequence $\left(\mathbf{5}^{\prime} \mathbf{3}^{\prime}\right)$} & Position \\
\hline pheS-21-F & CAYCCNGCHCGYGAYATGC & 557 \\
pheS-22-R & CCWARVCCRAARGCAAARCC & 1031 \\
pheS-23-R & GGRTGRACCATVCCNGCHCC & 968 \\
& & \\
\hline
\end{tabular}

were clearly differentiated from all other enterococcal species with validly published names (see Supplementary Fig. S1 in IJSEM Online). The closest species was E. sulfureus, with $79 \cdot 4 \%$ sequence similarity. Our results show that the comparison of pheS gene sequence data is an efficient screening method for the detection of novel enterococcal species.

For DNA base composition analysis, high-molecular-mass DNA from bacterial cells grown on Todd-Hewitt broth (Oxoid) at $37^{\circ} \mathrm{C}$ was isolated as described by Mannerová et al. (2003). Degradation of the isolated DNA into nucleosides and their separation by HPLC was performed as described by Vancanneyt et al. (2004). The DNA G+C content of strains LMG $16607^{\mathrm{T}}$ and LMG 16612 was $38 \cdot 7 \mathrm{~mol} \%$.

Growth and biochemical tests were carried out as described by Švec et al. (2001). A search for Lancefield antigens was performed with a Streptococcal grouping kit (Oxoid). The results are given in the species description below. The two analysed strains revealed identical biochemical profiles, enabling them to be differentiated from other enterococcal species. Strains LMG $16607^{\mathrm{T}}$ and LMG 16612 could be differentiated from the majority of known enterococcal species by their inability to produce acid from ribose. Ribose 
Table 2. Phenotypical tests useful for the differentiation of $E$. aquimarinus sp. nov. from the closest phylogenetic relatives, E. sulfureus, E. italicus, E. saccharominimus and $E$. saccharolyticus, and from another ribose-negative species, E. asini

Taxa: 1, E. aquimarinus sp. nov.; 2, E. saccharolyticus; 3, E. sulfureus; 4, E. italicus; 5, E. saccharominimus; 6, E. asini. Data for E. aquimarinus sp. nov. were obtained in this study; data for other taxa were reported by de Vaux et al. (1998), Farrow et al. (1984), Fortina et al. (2004), Martinez-Murcia \& Collins (1991) and Vancanneyt et al. (2004). +, Positive; -, negative.

\begin{tabular}{|lcccccc|}
\hline Characteristic & $\mathbf{1}$ & $\mathbf{2}$ & $\mathbf{3}$ & $\mathbf{4}$ & $\mathbf{5}$ & $\mathbf{6}$ \\
\hline Pigment production & - & - & + & - & - & - \\
Pyrrolidonyl arylamidase & + & - & + & + & + & + \\
$\beta$-Glucuronidase & - & + & - & - & - & - \\
Hippurate hydrolysis & - & - & - & - & - & + \\
Acidification of: & & & & & & \\
$\quad$ D-Arabitol & - & + & - & - & - & - \\
L-Arabinose & + & - & - & - & - & - \\
Gluconate & - & - & + & - & - & - \\
Inulin & + & + & - & - & - & - \\
Melezitose & - & + & + & - & - & - \\
Melibiose & + & + & + & - & - & - \\
D-Raffinose & + & + & + & - & - & - \\
Ribose & - & + & + & - & - & - \\
Sucrose & + & + & + & + & + & - \\
D-Xylose & + & - & - & - & - & + \\
\hline
\end{tabular}

acidification is considered to be typical for the genus Enterococcus, although several of the more recently described species, e.g. E. asini, E. italicus and E. saccharominimus, are negative for this trait. Table 2 shows phenotypical tests that are useful for the differentiation of strains LMG $16607^{\mathrm{T}}$ and LMG 16612 from their closest phylogenetic relatives, E. sulfureus, E. italicus, E. saccharominimus and E. saccharolyticus, and from another ribose-negative species, E. asini.

The overall results of the present study allowed us to assign strains LMG $16607^{\mathrm{T}}$ and LMG 16612 to a novel species for which we propose the name Enterococcus aquimarinus sp. nov.

\section{Description of Enterococcus aquimarinus sp. nov.}

Enterococcus aquimarinus (a.qui.ma.ri'nus. L. fem. n. aqua water; L. adj. marinus of the sea; N.L. masc. adj. aquimarinus pertaining to sea water).

Cells are elongated, often lanceolate. They occur singly or in small groups and predominantly in pairs. The type strain grows equally well at 25 and $42{ }^{\circ} \mathrm{C}$. Addition of $5 \% \mathrm{CO}_{2}$ does not enhance growth. Colonies on Columbia agar with sheep blood are small $(1-2 \mathrm{~mm})$, not pigmented, translucent, shining and regular. Greening haemolysis. Turbid growth in liquid media with a deposit. Grows in the presence of $6.5 \%$ $\mathrm{NaCl}$. Grows and produces blackening on bile aesculin agar. Poor growth on Slanetz and Bartley medium containing $0.04 \%$ sodium azide. Not motile. No detectable Lancefield antigens. Positive in tests for pyrrolidonyl arylamidase and for $\alpha$ - and $\beta$-galactosidase. Arginine hydrolysis is negative. Acid is produced from L-arabinose, D-xylose, galactose, glucose, fructose, mannose, $\mathrm{N}$-acetylglucosamine, arbutin, salicin, cellobiose, maltose, lactose, melibiose, sucrose, trehalose, inulin, raffinose, starch and turanose. Negative in Voges-Proskauer test and tests for hippurate, $\beta$ glucuronidase and alkaline phosphatase. No acid produced from glycerol, erythritol, D-arabinose, ribose, L-xylose, adonitol, methyl $\beta$-glucoside, sorbose, rhamnose, dulcitol, inositol, mannitol, sorbitol, methyl $\alpha$-D-mannoside, methyl $\alpha$-glucoside, amygdalin, melezitose, glycogen, xylitol, $\beta$ gentiobiose, lyxose, tagatose, D- or L-fucose, D- or Larabitol, gluconate or 2- or 5-ketogluconate. DNA G+C content is $38.7 \mathrm{~mol} \%$.

The type strain, LMG $16607^{\mathrm{T}}\left(=\mathrm{CCM} 7283^{\mathrm{T}}\right)$, was isolated from sea water.

\section{Acknowledgements}

P. S. thanks the Belgian Federal Science Policy Office for a research fellowship in the framework of the promotion of S\&T cooperation with Central and Eastern Europe. We thank bioMérieux for providing both sea-water isolates. This work was supported in part by the Ministry of Education of the Czech Republic (MSM 0021622416).

\section{References}

De Graef, E. M., Devriese, L. A., Vancanneyt, M., Baele, M., Collins, M. D., Lefebvre, K., Swings, J. \& Haesebrouck, F. (2003). Description of Enterococcus canis sp. nov. from dogs and reclassification of Enterococcus porcinus Teixeira et al. 2001 as a junior synonym of Enterococcus villorum Vancanneyt et al. 2001. Int J Syst Evol Microbiol 53, 1069-1074.

de Vaux, A., Laguerre, G., Divies, C. \& Prevost, H. (1998). Enterococcus asini sp. nov. isolated from the caecum of donkeys (Equus asinus). Int J Syst Bacteriol 48, 383-387.

Devriese, L. A. \& Pot, B. (1995). The genus Enterococcus. In The Genera of Lactic Acid Bacteria, pp. 327-367. Edited by B. J. B. Wood \& W. H. Holzapfel. London: Blackie Academic \& Professional.

Devriese, L. A., Collins, M. D. \& Wirth, R. (1992). The genus Enterococcus. In The Prokaryotes: A Handbook on the Biology of Bacteria: Ecophysiology, Isolation, Identification, Applications, pp. 1465-1481. Edited by A. Balows, H. G. Trüper, M. Dworkin, W. Harder \& K. H. Schleifer. New York: Springer.

Devriese, L. A., Pot, B. \& Collins, M. D. (1993). Phenotypic identification of the genus Enterococcus and differentiation of phylogenetically distinct enterococcal species and species groups. J Appl Bacteriol 75, 399-408.

Devriese, L. A., Vancanneyt, M., Descheemaeker, P., Baele, M., Van Landuyt, H. W., Gordts, B., Butaye, P., Swings, J. \& Haesebrouck, F. (2002). Differentiation and identification of Enterococcus durans, E. hirae and E. villorum. J Appl Microbiol 92, 821-827.

Domig, K. J., Mayer, H. K. \& Kneifel, W. (2003). Methods used for the isolation, enumeration, characterisation and identification of 
Enterococcus spp. 2. Pheno- and genotypic criteria. Int J Food Microbiol 88, 165-188.

Farrow, J. A. E., Kruze, J., Phillips, B. A., Bramley, A. J. \& Collins, M. D. (1984). Taxonomic studies on Streptococcus bovis and Streptococcus equinus: description of Streptococcus alactolyticus sp. nov. and Streptococcus saccharolyticus sp. nov. Syst Appl Microbiol 5, 467-482.

Fortina, M. G., Ricci, G., Mora, D. \& Manachini, P. L. (2004). Molecular analysis of artisanal Italian cheeses reveals Enterococcus italicus sp. nov. Int J Syst Evol Microbiol 54, 1717-1721.

Gevers, D., Huys, G. \& Swings, J. (2001). Applicability of rep-PCR fingerprinting for identification of Lactobacillus species. FEMS Microbiol Lett 205, 31-36.

Hall, T. A. (1999). BioEdit: a user-friendly biological sequence alignment editor and analysis program for Windows 95/98/NT. Nucleic Acids Symp Ser 41, 95-98.

Mannerová, S., Pantůček, R., Doškař, J., Švec, P., Snauwaert, C., Vancanneyt, M., Swings, J. \& Sedláček, I. (2003). Macrococcus brunensis sp. nov., Macrococcus hajekii sp. nov. and Macrococcus lamae sp. nov., from the skin of llamas. Int J Syst Evol Microbiol 53, 1647-1654.

Martinez-Murcia, A. J. \& Collins, M. D. (1991). Enterococcus sulfureus, a new yellow-pigmented Enterococcus species. FEMS Microbiol Lett 80, 69-73.

Naser, S. M., Thompson, F. L., Hoste, B., Gevers, D., Dawyndt, P., Vancanneyt, M. \& Swings, J. (2005). Application of multilocus sequence analysis (MLSA) for rapid identification of Enterococcus species based on rpoA and pheS genes. Microbiology 151, 2141-2150.

Pot, B., Vandamme, P. \& Kersters, K. (1994). Analysis of electrophoretic whole-organism protein fingerprints. In Modern Microbiological Methods: Chemical Methods in Prokaryotic Systematics, pp. 493-521. Edited by M. Goodfellow \& A. G. O’Donnell. Chichester: Wiley.

Raes, J. \& Van de Peer, Y. (1999). ForCon: a software tool for the conversion of sequence alignments. http://www.ebi.ac.uk/embnet. news/vol6_1/ForCon/body_forcon.html

Stackebrandt, E. \& Goebel, B. M. (1994). Taxonomic note: a place for DNA-DNA reassociation and 16S rRNA sequence analysis in the present species definition in bacteriology. Int J Syst Bacteriol 44, 846-849.

Švec, P., Devriese, L. A., Sedláček, I., Baele, M., Vancanneyt, M., Haesebrouck, F., Swings, J. \& Doškař, J. (2001). Enterococcus haemoperoxidus sp. nov. and Enterococcus moraviensis sp. nov., isolated from water. Int J Syst Evol Microbiol 51, 1567-1574.

Vancanneyt, M., Zamfir, M., Devriese, L. A. \& 7 other authors (2004). Enterococcus saccharominimus sp. nov., from dairy products. Int J Syst Evol Microbiol 54, 2175-2179.

Van de Peer, Y. \& De Wachter, R. (1994). TREECON for Windows: a software package for the construction and drawing of evolutionary trees for the Microsoft Windows environment. Comput Appl Biosci 10, 569-570. 